\title{
PENGARUH ACTIVITY SUPPORT TERHADAP KUALITAS VISUAL KORIDOR JALAN K.H. AGUS SALIM SEMARANG
}

\author{
Iswatun Hasanah*), Bambang Setioko, Erni Setyowati \\ Program Studi Magister Teknik Arsitektur, Fakultas Teknik, Universitas Diponegoro, \\ Jl. Hayam Wuruk 5, Kampus Undip Pleburan, Semarang, Indonesia
}

\begin{abstract}
Abstrak
Koridor Jalan K.H. Agus Salim merupakan koridor komersial yang cukup ramai yang berada di Wilayah Kecamatan Semarang Tengah di Kota Semarang. Pada koridor jalan ini terdapat beberapa bangunan yang menjadi magnet pemicu aktivitas-aktivitas yang bermunculan atau disebut activity support di sepanjang jalan ini. Sebagian ruang di koridor Jalan K.H. Agus Salim Semarang dipenuhi oleh activity support berupa pedagang kaki lima dan beberapa pangkalan becak. Ibaratnya sebuah generator, Jalan K.H. Agus Salim menjadi akses termudah bagi perkembangan aktivitas tersebut. Dengan demikian diduga activity support yang berada di sepanjang koridor Jalan K.H. Agus Salim ini berpengaruh pada kualitas visualnya. Untuk mengetahui pengaruh tersebut, maka penelitian ini menggunakan metode kuantitatif rasionalistik. Metode pengumpulan data berupa studi literatur, observasi lapangan, wawancara, dan kuisioner. Metode analisis data yang digunakan berupa analisis statistik dengan uji regresi menggunakan program SPSS 21.0 for Windows. Hasil dari penelitian ini menunjukkan adanya pengaruh antara activity support terhadap kualitas visual koridor jalan.
\end{abstract}

Kata kunci: activity support; kualitas visual; koridor jalan

\begin{abstract}
[Influence of Activity Support towards Visual Quality of KH. Agus Salim Semarang Road Corridor] Road corridor of K.H. Agus Salim is a quite crowded commercial corridor which is located in the Regional District of Central Semarang City. On this road corridor, there are several buildings that make magnets trigger for emerging activities or also known as activity support along this road. The majority space on the road corridor is fullfilled with activity support in the form of street vendors and rickshaw bases. It is like a generator, road K.H. Agus Salim become the easiest access to the development of the activity. Thus, it is supposed that activity support along the road corridor of KH Agus Salim effect on the visual quality. To determine the effects, this research used quantitative rationalistic methods. Methods of data collection are literature study, field observations, interview and questionnaires. Method of data analysis using statistical analysis by regression test using program SPSS for Windows 21.0. The results of this study found out there were some influences of the activity support to the visual quality of the road corridor.
\end{abstract}

Keywords: activity support; visual quality; road corridor

\section{Pendahuluan}

Kehidupan suatu kota dapat terwakili keberadaannya melalui sebuah jalan. Jalan menjadi akses penting bagi setiap masyarakat untuk dapat menghubungkannya kemana saja sehingga masyarakat dapat beraktivitas sesuai dengan kebutuhannya. Menurut Krier (1979) aktivitas pada sebuah kota akan muncul pada area publik seperti square dan jalan. Aktivitas masyarakat yang didukung oleh sebuah activity support inilah yang akan berpengaruh terhadap perkembangan sebuah kota. Activity support juga dapat berperan sebagai komunikator untuk

\footnotetext{
${ }^{*}$ Penulis Korespondensi.

E-mail: iishasanah25@ymail.com
}

menciptakan kualitas ruang kota yang kontinu atau menerus antara suatu fungsi aktivitas dengan fungsi aktivitas yang lain. Kontinuitas yang menerus ini diharapkan dapat memberikan kesan visual yang spesifik pada kawasan tertentu dan menghadirkan identitas lokal kawasan.

Fungsi utama activity support adalah menghubungkan dua atau lebih pusat aktivitas umum dan menggerakkan fungsi aktivitas utama kota menjadi lebih hidup, menerus dan ramai (Shirvani, 1985). Mazumdar (2010) mengatakan bahwa suatu urban design khususnya pada rancangan sebuah jalan yang baik juga akan menguntungkan aktivitas lainnya seperti pemicu munculnya activity support di jalan tersebut. Tujuannya adalah untuk menciptakan kehidupan kota menjadi sempurna dan lebih baik yang 
dengan mudah mengakomodasikan kebutuhan atau barang keperluan sehari-hari untuk masyarakat. Public space seperti Pasar Johar yang ada di Jalan K.H. Agus Salim Semarang merupakan pemicu hadirnya activity support. Faktanya sebagian ruang koridor jalan dipenuhi activity support berupa pedagang kaki lima dan pangkalan becak. Activity support yang hadir di koridor jalan membuat kualitas visual koridornya ikut terpengaruhi juga.

Moughtin (2003) berpendapat bahwa aktivitas pada square atau jalan berpengaruh terhadap vitalitas jalan itu sendiri dan juga pada kualitas visualnya. Kivanc (2013) menambahkan bahwa selain elemen lanskap sebagai content dalam suatu lingkungan, aktivitas manusia juga ikut mempengaruhi kualitas visual sebuah lingkungan. Kondisi di lapangan yang dapat diamati saat ini yaitu menyatunya sirkulasi pejalan kaki, activity support, dan kendaraan yang melewati jalan tanpa adanya sebuah perencanaan yang baik merupakan masalah-masalah yang berpengaruh pada kualitas visual koridor jalan.

Kualitas visual koridor merupakan nilai yang diperoleh dari suatu sumber yang dapat diamati atau dilihat secara visual oleh pengamat (Smardon et,al., 1986). Berbeda halnya dengan karakter visual yang membahas keunikan atau ciri khas yang ada pada satu lingkungan atau koridor, kualitas visual membahas penilaian dari seorang pengamat terhadap sebuah lingkungan atau koridor. Bagaimana perasaan dan kesan pengamat saat berada di koridor jalan merupakan poin utama yang dicari dari penelitian mengenai kualitas visual koridor jalan.

Tujuan penelitian ini adalah untuk mengetahui pengaruh activity support terhadap kualitas visual koridor. Untuk mengukur activity support digunakan teori Ching (2000) dalam menilai visual suatu bentuk. Activity support sebagai sumber visualnya dapat dikaji berdasarkan teori bentuk yang dikemukakan oleh Ching (2000), yaitu melalui faktor bentuk/wujud, dimensi, warna, tekstur/susunan, dan posisi yang dapat ditinjau dan diukur pengaruhnya terhadap aspek sistem dan kualitas visual: optic, place, content (Cullen, 1961), keterpaduan, proporsi, keseimbangan, irama, dan warna (Moughtin, 1999).

\section{Metode Penelitian}

Kota Semarang sebagai ibu Kota Jawa Tengah tentunya mengalami berbagai perkembangan yang cukup pesat. Munculnya bangunan-bangunan komesial seperti pasar, mall, dan perkantoran di Semarang merupakan tanda bahwa Semarang tidak kalah jauh dengan beberapa kota besar lainnya. Maraknya pembangunan fasilitas-fasilitas tersebut ternyata diikuti juga oleh tumbuhnya activity support di koridor jalan.

Jalan K.H. Agus Salim adalah salah satu koridor komersial yang berada di kawasan perdagangan Johar Semarang dan juga merupakan batas sebelah selatan kawasan konservasi Kota Lama Semarang. Koridor jalan ini pun ikut menjadi saksi sejarah panjang urban design di Kota Semarang ditandai dengan aneka ragam bangunan yang ada di koridor jalan ini.

Dilihat dari fungsinya, kawasan Jalan K.H. Agus Salim ini masuk ke dalam kawasan perdagangan dan jasa. Berdasarkan hal tersebut, pada penelitian ini diputuskan untuk meneliti sepanjang Jalan K.H. Agus Salim karena aktivitas di sepanjang jalan ini memiliki karakteristik yang sama saja yaitu mempunyai kegiatan perdagangan dan jasa.

Untuk lebih jelasnya, Gambar 1-3 menunjukkan lokasi koridor jalan K.H. Agus Salim ditinjau dari Kota Semarang (Analisis pada peta BPN tahun 2013 dan hasil survei lapangan tahun 20132014).

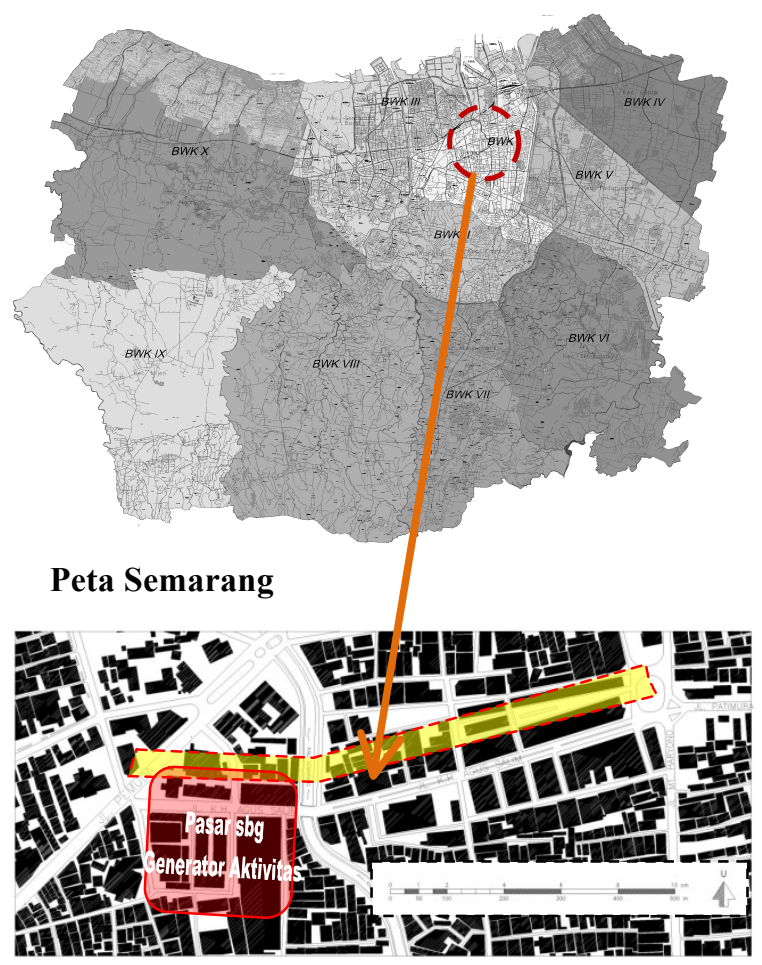

Gambar 1. Lokasi koridor Jalan K.H. Agus Salim Semarang

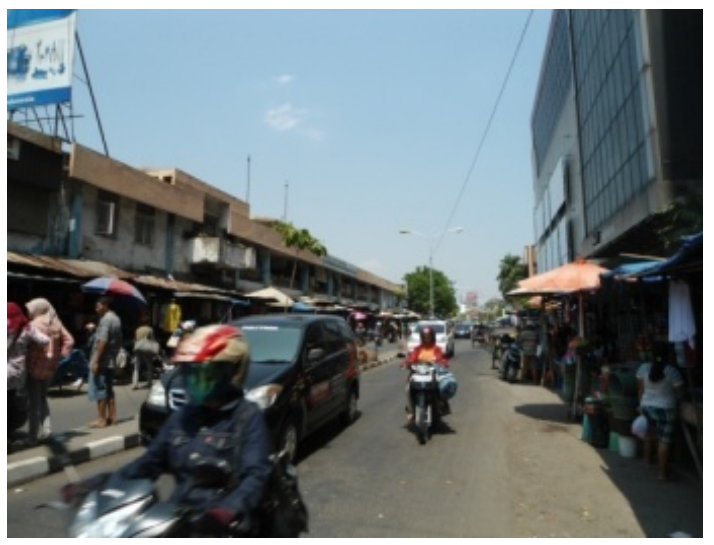

Gambar 2. Suasana koridor Jalan K.H. Agus Salim Semarang pada siang hari 


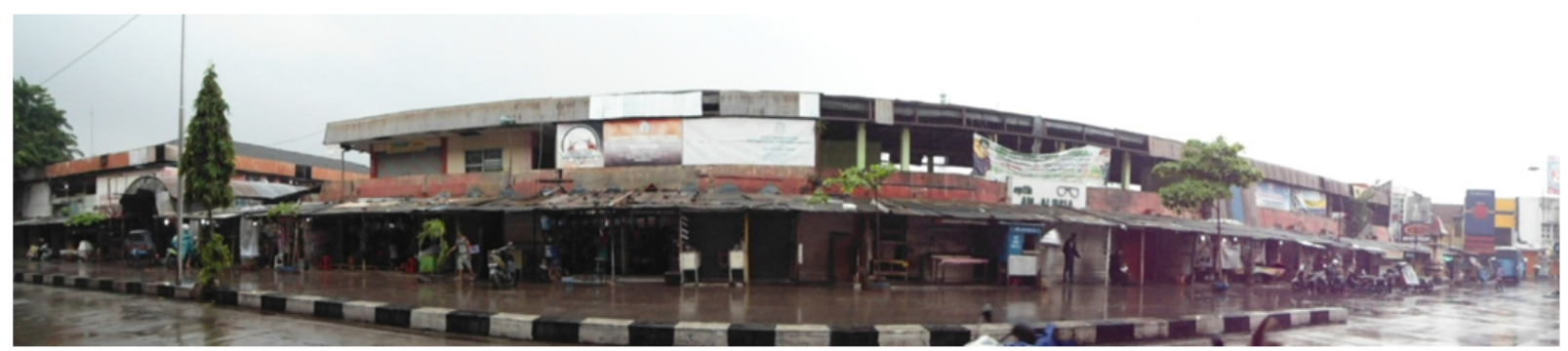

Gambar 3. Panorama koridor jalan di depan Pasar Yaik pada saat pagi hari

\section{Activity Support sebagai Elemen Visual Koridor}

Kawasan komersial tidak dapat dipisahkan dengan activity support yang mendukung kawasan tersebut setiap harinya. Activity support seperti menjadi identitas suatu kawasan komersial. Terdapat beragam macam activity support. Kios pedagang kaki lima, kios tambal ban, pangkalan becak, dan rumah toko merupakan macam-macam activity support yang berada di Jalan ini. Macam activity support yang mendominasi adalah kios semi permanen, kios berbentuk tenda, dan gerobak yang menyediakan kebutuhan sehari-hari. Segala bentuk aktivitas, pendukung aktivitasnya dan sirkulasi jalan menjadi satu padu di jalan dan menimbulkan kepadatan disepanjang jalan ini apalagi saat jam sibuk kerja.

Menurut Ching (2000), terdapat beberapa parameter yang dapat digunakan untuk menilai visual suatu bentuk. Activity support pun dapat dianalisa dan dinilai visualnya melalui teori bentuk yang dikemukakan oleh Ching, yaitu melaui faktor bentuk, dimensi, warna, tekstur/susunan, dan posisi.

1. Bentuk

Terdapat 3 macam bentuk pedagang kaki lima yang berada di Jalan K.H. Agus Salim, yaitu:

- Pedagang kaki lima dengan bentuk kios semi permanen (Gambar 4, Hasil survei lapangan tahun 2013). Kebanyakan kios seperti ini beratapkan seng dan terpal serta terdapat beberapa kios berlantaikan keramik. Kios ini berderet di depan bangunan Pasar Johar dan Pasar Yaik juga posisinya memakan jalur sirkulasi pejalan kaki atau trotoar.

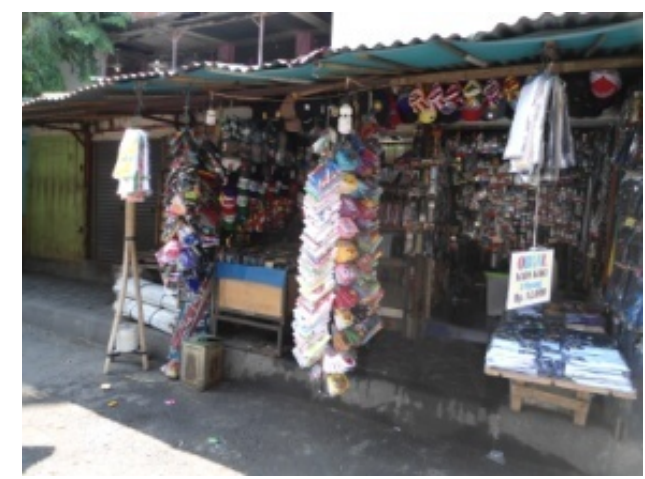

Gambar 4. Activity support yang berbentuk kios
- Pedagang kaki lima dengan bentuk tenda (Gambar 5, Hasil survei lapangan tahun 2013). Bentuk ini biasanya terdapat di pinggir jalan atau memakan badan jalan. Kios PKL dengan bentuk tenda ini bersifat non permanen karena dapat dibongkar pasang dan hanya beratapkan seperti payung dijadikan seperti tenda bagi pedagangnya. Pedagang tenda ini memenuhi jembatan di Jalan K.H. Agus Salim dan beberapa terdapat berpencar di sepanjang jalan.

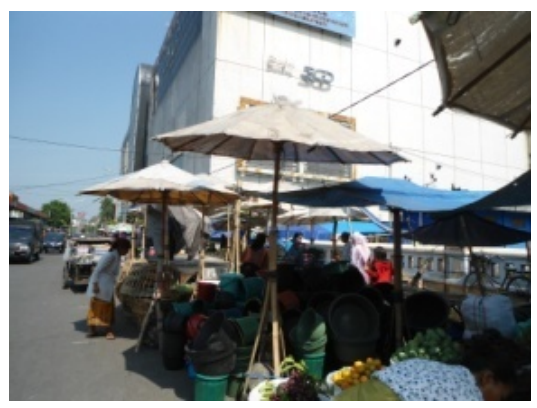

Gambar 5. Activity support yang berbentuk tenda

- Pedagang kaki lima dengan bentuk gerobak (Gambar 6, Hasil survei lapangan tahun 2013). Jenis ini bersifat non permanen karena bisa di bawa kemana-mana. Kebanyakan gerobak di jalan ini bermaterialkan kayu, selain itu biasanya gerobak-gerobak di sini menambahkan terpal untuk melindungi dari sinar matahari. Bentuk gerobak ini menyebar di sepanjang jalan.

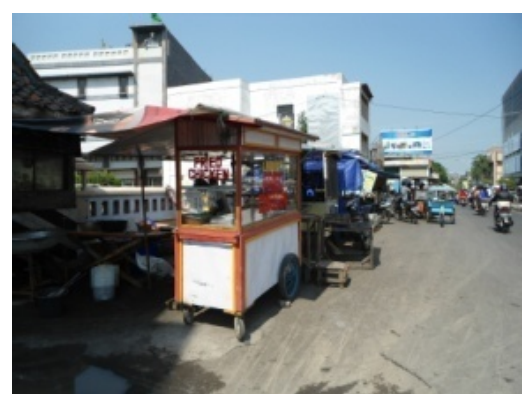

Gambar 6. Activity support yang berbentuk gerobak 


\section{Dimensi}

Penilaian dimensi activity support dalam penelitian ini dilihat dari ukurannya dan jarak masing-masing activity support itu sendiri. Pada objek penelitian ini, khususnya kios non permanen ada yang luasnya sekitar 1,5 meter namun tidak sedikit pula yang luasnya melebihi 1,5 meter. Jalur pejalan kaki pun harus hilang karena keberadaan kios-kios yang sudah menempatinya dari sejak 20 tahunan yang lalu itu.

Berbicara mengenai jarak, terdapat activity support yang berderet dan berpencar. Yang paling mendominasi koridor jalan ini adalah activity support yang berderet. Kios-kios nonpermanen dengan bentuk yang sama berderet dan memiliki jarak yang rapat satu sama lain yang posisinya berada di atas jalur pejalan kaki di depan bangunan Pasar Yaik dan Pasar Johar Semarang. Kios-kios yang berderet dan berjarak ini memberikan pengaruh terhadap faktor irama pada kualitas visual koridor jalan (Gambar 7, Hasil survei lapangan tahun 2013).

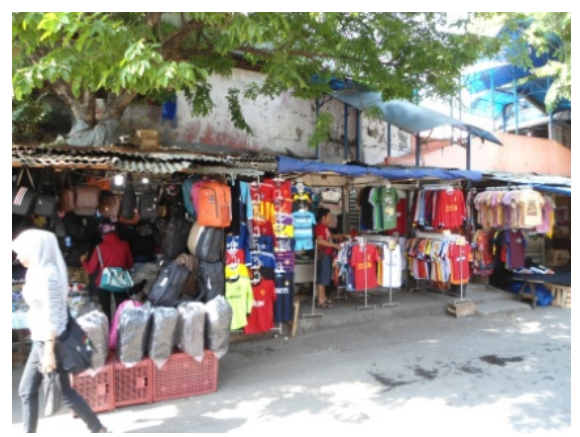

Gambar 7. Kios semi permanen yang memakan jalur pejalan kaki di jalan K.H. Agus Salim

3. Warna

Warna senada seperti abu-abu dan coklat dan ditemukan dalam objek penelitian ini (Gambar 8, Hasil survei lapangan tahun 2013). Warna-warna terang seperti merah, kuning dan biru hanya sedikit ditemukan bahkan sangat jarang ditemukan. Pencahayaan activity support pada malam harinya pun hanya didominasi oleh lampu yang terang dan tidak berwarna-warni. Hal ini dikarenakan keadaan koridor jalan yang gelap dan pengunjung yang datang pun tidak seramai di siang harinya. Selain itu hanya beberapa activity support yang ada di koridor jalan pada malam hari.

4. Tekstur

Pada activity support, tekstur merupakan susunan atau bahan material pembentuk acivity support itu sendiri. Tekstur atau susunan material yang ditemukan pada activity support yang dominan adalah material kayu. Hampir semua activity support bermaterialkan kayu sehingga memiliki tekstur tersendiri yang dihadirkan dalam activity support di koridor jalan K.H. Agus Salim ini.

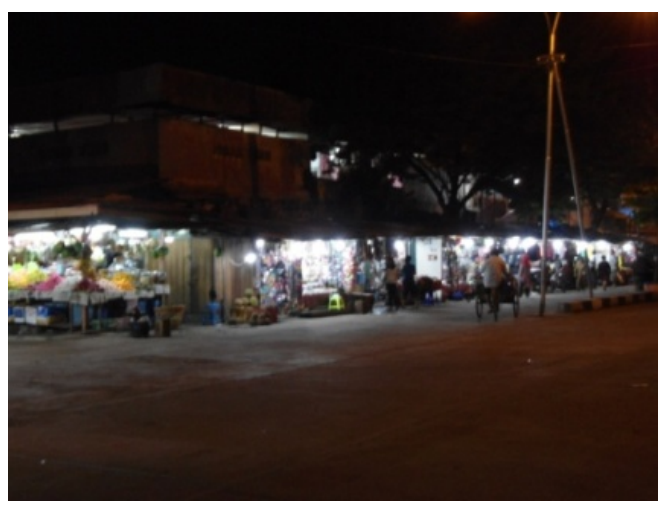

Gambar 8. Pencahayaan beberapa activity support pada malam hari

5. Posisi

Posisi PKL di sepanjang koridor jalan K.H. Agus Salim ini berada di atas area pejalan kaki dan sebagian lagi memakan badan jalan / pinggir jalan. Posisi activity support yang berada di jalur pejalan kaki maupun yang berada di pinggir jalan, akan memberikan nilai pengaruh yang berbeda pula.

Untuk menunjang tujuan penelitian, maka materi penelitian yang dipakai merupakan gabungan dari beberapa materi-materi yakni materi penelitian berupa literatur baik yang berasal dari buku, jurnal, artikel ilmiah, proceeding maupun sumber lain yang berkaitan dengan teori activity support dan kualitas visual koridor jalan serta materi penelitian yang didapatkan dari observasi lapangan. Alat yang digunakan untuk pengumpulan data antara lain peta, berupa peta citra maupun peta dari BPN untuk mengetahui daerah yang sudah diamati, pemetaan tata guna lahan, dll. Kamera digunakan untuk merekam secara visual bangunan, ruang serta pemandangan yang terbentuk. Kertas dan alat tulis untuk merekam secara visual tampak atau fasade bangunan yang diteliti. Kuesioner sebagai alat untuk mendapatkan informasi dari setiap responden serta tabel dan grafik sebagai alat untuk analisis.

Metode penelitian yang dipakai dalam penelitian ini adalah paradigma rasionalistik dengan pendekatan kuantitatif, yaitu metode penelitian yang berlandaskan pada filsafat rasionalisme. Penelitian ini membandingkan teori yang telah ada dengan kenyataan yang terjadi di lapangan. Tujuan digunakannya metode kuantitatif yaitu untuk mendata objek fisik di lokasi penelitian secara objektif dalam tampilan angka untuk selanjutnya dilakukan analisa secara rasionalistik.

Dalam penelitian ini, variabel penelitian dibedakan menjadi variabel bebas dan variabel terikat. Yang menjadi variabel bebas adalah activity support. Adapun subvariabel pada variabel bebas tersebut yaitu bentuk, warna, dimensi, tekstur dan posisi. Sedangkan 
variabel terikat yang digunakan adalah kualitas visual koridor jalan. Adapun sub variabel pada variabel terikat tersebut adalah optic, place, content, keterpaduan, proporsi, keseimbangan, irama, dan warna.

Yang menjadi populasi berasal dari pengguna kawasan, yaitu masyarakat yang secara rutin melakukan aktivitas di lokasi penelitian, sehingga dirasa cukup memiliki kesan mendalam terhadap lokasi penelitian yaitu di sepanjang jalan K.H. Agus Salim. Pengguna kawasan atau dapat dikatakan sebagai pengamat membutuhkan pengamatan berulang kali agar dapat memahami suatu objek secara benar (Wang, 2006), maka dari itu pengguna kawasan dibagi menjadi dua yaitu:

a. Penghuni (baik yang tempat tinggalnya di sekitar objek penelitian, maupun pedagang atau pelayan toko). Kriteria ini diambil dengan pertimbangan penghuni dianggap lebih tahu dan sudah paham dengan lokasi penelitian karena setiap hari melewatinya, dan

b. Pengunjung (Masyarakat yang pernah melewati objek penelitian lebih dari satu kali dalam satu bulan). Kriteria ini diambil karena pengunjung tersebut dianggap telah memahami objek karena sering melewatinya.

Responden dibatasi dalam usia 15-59 tahun, usia yang dianggap dapat memahami maksud dari pertanyaan yang diajukan peneliti. Besarnya populasi penelitian tidak diketahui secara pasti. Karena objek penelitian merupakan public space yang setiap harinya dikunjungi pengunjung yang tidak menentu jumlahnya serta tidak adanya data yang pasti tentang jumlah pengunjung di kawasan ini. Berdasarkan kondisi yang ada, teknik sampling yang dipakai dalam penelitian ini adalah teknik sampling insidental/accidental sampling.

Berdasarkan teori yang dikemukakan oleh Sugiyono (2009) bahwa ukuran sampel yang layak dalam sebuah penelitian adalah minimal 30 orang responden dan maksimal 500 orang. Persyaratan lain yang digunakan untuk mengukur sampel yaitu bila sampel dibagi dalam kategori maka jumlah sampel setiap kategori dibagi menjadi minimal 30. Berdasarkan persyaratan tersebut, besar sampel penelitian ini sejumlah 100 orang yang dianggap mengenal dan mengetahui lokasi penelitian. Kategori dalam penelitian ini disajikan di Tabel 1 (data penelitian tahun 2013).

\section{Hasil dan Pembahasan}

Berdasarkan perhitungan sampel pada Bab Metode Penelitian, jumlah responden yang dibutuhkan adalah sebanyak 100 sampel. Setelah dilakukan penyebaran kusioner didapatkan hasil responden seperti disajikan di Tabel 2 (Data penelitian tahun 2014).
Tabel 1. Responden penelitian

\begin{tabular}{|c|c|c|c|}
\hline \multicolumn{2}{|c|}{ Identitas responden } & Jumlah & Persentase \\
\hline \multirow{4}{*}{$\begin{array}{l}\text { Tempat } \\
\text { Tinggal }\end{array}$} & Dekat & 36 & $36 \%$ \\
\hline & Jauh & 47 & $47 \%$ \\
\hline & Ubstain & 17 & $17 \%$ \\
\hline & Total & 100 & $100 \%$ \\
\hline \multirow{4}{*}{$\begin{array}{c}\text { Durasi } \\
\text { Melewati }\end{array}$} & Setiap Hari & 45 & $45 \%$ \\
\hline & 1x Seminggu & 48 & $48 \%$ \\
\hline & $<1 \mathrm{x}$ Seminggu & 7 & $7 \%$ \\
\hline & Total & 100 & $100 \%$ \\
\hline \multirow{6}{*}{ Pekerjaan } & Karyawan & 36 & $36 \%$ \\
\hline & Pelajar & 35 & $35 \%$ \\
\hline & PNS & 4 & $4 \%$ \\
\hline & Wirausaha & 30 & $30 \%$ \\
\hline & Lain-lain & 5 & $5 \%$ \\
\hline & Total & 100 & $100 \%$ \\
\hline \multirow{7}{*}{$\begin{array}{c}\text { Kelompok } \\
\text { Usia }\end{array}$} & Dibawah 18th & 9 & $9 \%$ \\
\hline & $18-25$ th & 36 & $36 \%$ \\
\hline & $26-35$ th & 23 & $23 \%$ \\
\hline & $36-45$ th & 19 & $19 \%$ \\
\hline & $46-55$ th & 8 & $8 \%$ \\
\hline & Diatas 55th & 5 & $5 \%$ \\
\hline & Total & 100 & $100 \%$ \\
\hline
\end{tabular}

Tabel 2. Data responden penelitian

\begin{tabular}{clc}
\hline No. & Jenis Responden & Jumlah \\
\hline 1. & $\begin{array}{l}\text { PENGHUNI (Pemilik } \\
\text { bangunan, masyarakat yang } \\
\text { beraktivitas seharian di lokasi) }\end{array}$ & 50 \\
\hline 2. & $\begin{array}{l}\text { PENGUNJUNG (Masyarakat } \\
\text { yang sering mengunjungi atau } \\
\text { melintasi lokasi, berbelanja, } \\
\text { termasuk yang mengerti ilmu } \\
\text { arsitektur) }\end{array}$ & 50 \\
\hline & \multicolumn{1}{c}{ Jumlah } & 100 \\
\hline
\end{tabular}

Berdasarkan data keseluruhan responden terlihat bahwa mayoritas pengguna kawasan adalah yang tempat tinggalnya jauh dengan di dominasi oleh pengunjung yang berusia antara 18-25 tahun.

Penelitian ini menggunakan metode analisis deskriptif untuk menggambarkan kondisi yang dirasakan responden mengenai variabel yang dijadikan model penelitian. Metode deskriptif pada suatu kumpulan data penelitian biasanya menggunakan nilai mean. Cara untuk mencari nilai mean dapat menggunakan 2 cara, yakni menggunakan software SPSS maupun rumus mencari nilai mean. Pada dasarnya nilai mean dihitung dari jumlah nilai keseluruhan responden dibagi jumlah responden.

Berdasarkan analisis deskriptif ini, maka didapatkan perbandingan hasil tiap analisis untuk mengetahui faktor mana yang menonjol dan faktor mana yang tidak. Dengan begitu dapat diketahui seberapa besar pengaruh masing-masing faktor terhadap variabel yang disusunnya. Hasil keseluruhan pengolahan nilai mean diketahui faktor-faktor yang paling menonjol dapat digambarkan pada Tabel 3 .

Faktor yang dominan menurut penghuni adalah faktor bentuk dan optic (lihat Tabel 3). Menurut 
pengunjung, faktor yang paling dominan adalah faktor bentuk dan place. Hasil olahan keseluruhan data pada keseluruhan responden, faktor yang paling dominan adalah bentuk dan optic, sedangkan faktor lainnya seperti dimensi, warna, susunan, posisi, place, content, keterpaduan, proporsi, keseimbangan, dan irama kurang dominan.

Tabel 3. Perbandingan nilai mean per faktor

\begin{tabular}{llccc}
\hline Variabel & Faktor & $\begin{array}{c}\text { Peng- } \\
\text { huni }\end{array}$ & $\begin{array}{c}\text { Pengun } \\
\text {-jung }\end{array}$ & $\begin{array}{c}\text { Seluruh } \\
\text { Respon- } \\
\text { den }\end{array}$ \\
\hline \multirow{2}{*}{ Activity } & Bentuk & $\mathbf{3 . 2 7}$ & $\mathbf{3 . 5 1}$ & $\mathbf{3 . 7 0}$ \\
Support & Warna & 2.92 & 3.14 & 3.29 \\
& Susunan & 3.20 & 3.31 & 3.44 \\
& Posisi & 3.19 & 3.07 & 3.32 \\
& Optic & 2.81 & 2.81 & 3.28 \\
\hline \multirow{3}{*}{ Kualitas } & Place & 3.64 & 3.58 & $\mathbf{3 . 6 6}$ \\
Koridor & Kontent & 3.42 & $\mathbf{3 . 7 4}$ & 3.04 \\
& Proporsi & 2.92 & 2.95 & 2.94 \\
& Keseim- & 2.52 & 2.70 & 2.59 \\
& bangan & 2.68 & 2.75 & 2.71 \\
& Irama & 3.20 & 3.35 & 3.27 \\
& Warna & 3.50 & 3.72 & 3.63 \\
\hline
\end{tabular}

Metode analisis data berikutnya yang digunakan dalam penelitian ini adalah analisis regresi sederhana. Penelitian ini menggunakan analisis statistik dengan program komputer Statistical Product and Social Science (SPSS) 21.0 for Windows. Teknik analisa data yang digunakan dalam penelitian ini adalah teknik analisis regresi sederhana yang terbagi menjadi beberapa bagian yaitu uji validitas dan reliabilitas, uji normalitas, uji regresi, uji anova, dan uji $t$-test. Tabel 4-7 adalah hasil dari uji statistik data yang telah dilakukan dalam penelitian ini.

Tabel 4. Hasil Uji normalitas

\begin{tabular}{ccc}
\hline \multirow{2}{*}{ Responden } & \multicolumn{2}{c}{ Uji Normalitas } \\
\cline { 2 - 3 } & Nilai Asymp sig & Artinya \\
\hline Semua & $\mathrm{X}=0.687$ & Data berdistribusi \\
Responden & $\mathrm{Y}=0.524$ & secara normal \\
\hline \multirow{2}{*}{ Penghuni } & $\mathrm{X}=0.912$ & Data berdistribusi \\
& $\mathrm{Y}=0.626$ & secara normal \\
\hline \multirow{2}{*}{ Pengunjung } & $\mathrm{X}=0.634$ & Data berdistribusi \\
& $\mathrm{Y}=0.960$ & secara normal \\
\hline
\end{tabular}

Tabel 6. Hasil uji ANNOVA

\begin{tabular}{|c|c|c|}
\hline \multirow{2}{*}{ Responden } & \multicolumn{2}{|c|}{ Uji Normalitas } \\
\hline & Nilai Sig & Artinya \\
\hline $\begin{array}{c}\text { Semua } \\
\text { Responden }\end{array}$ & 0.000 & $\begin{array}{l}\text { Semua faktor activity } \\
\text { support yang }\end{array}$ \\
\hline Penghuni & 0.000 & model mempunyai \\
\hline Pengunjung & 0.000 & $\begin{array}{l}\text { bersama-sama } \\
\text { terhadap variabel } \\
\text { kualitas koridor jalan }\end{array}$ \\
\hline
\end{tabular}

Tabel 5. Hasil koefisien determinasi

\begin{tabular}{|c|c|c|}
\hline \multirow[t]{2}{*}{ Responden } & \multicolumn{2}{|c|}{ Koefisien Determinasi } \\
\hline & $\begin{array}{c}\text { Nilai R \& } \\
\text { Adj } R^{2}\end{array}$ & Artinya \\
\hline $\begin{array}{c}\text { Semua } \\
\text { Responden }\end{array}$ & $\begin{array}{l}\mathrm{R}: 0.598 \\
\text { Adj } \mathrm{R}^{2}: 0.352\end{array}$ & $\begin{array}{l}\text { Kedua variabel memiliki } \\
\text { pengaruh kuat \& positif. } \\
\text { Activity support } \\
\text { berpengaruh } 35.2 \% \\
\text { terhadap kualitas visual } \\
\text { koridor }\end{array}$ \\
\hline Penghuni & $\begin{array}{l}\mathrm{R}: 0.620 \\
\text { Adj } R^{2}: 0.371\end{array}$ & $\begin{array}{l}\text { Kedua variabel memiliki } \\
\text { pengaruh kuat \& positif. } \\
\text { Activity support } \\
\text { berpengaruh } 37.1 \% \\
\text { terhadap kualitas visual } \\
\text { koridor }\end{array}$ \\
\hline Pengunjung & $\begin{array}{l}\mathrm{R}: 0.557 \\
\text { Adj } \mathrm{R}^{2}: 0.296\end{array}$ & $\begin{array}{l}\text { Kedua variabel memiliki } \\
\text { pengaruh kuat \& positif. } \\
\text { Activity support } \\
\text { berpengaruh } 29.6 \% \\
\text { terhadap kualitas visual } \\
\text { koridor }\end{array}$ \\
\hline
\end{tabular}

Tabel 7. Hasil uji signifikasi $t$-test

\begin{tabular}{|c|c|c|}
\hline \multirow{2}{*}{ Responden } & \multicolumn{2}{|c|}{ Uji Signifikasi $t$-test } \\
\hline & Nilai Sig & Artinya \\
\hline $\begin{array}{c}\text { Semua } \\
\text { Responden }\end{array}$ & 0.000 & $\begin{array}{c}\text { Variabel X (activity } \\
\text { support) berpengaruh }\end{array}$ \\
\hline Penghuni & 0.000 & terhadap variabel Y \\
\hline Pengunjung & 0.000 & jalan) \\
\hline
\end{tabular}

Dari hasil uji statistika di atas terlihat bahwa kedua variabel penelitian terdistribusi secara normal. Nilai R yang didapat dari tabel summary yang diperoleh baik dari penghuni, pengunjung, maupun seluruh responden menyatakan bahwa hubungan antara activity support dan kualitas koridor adalah rendah. Semua faktor activity support yang dimasukkan dalam model mempunyai pengaruh terhadap variabel kualitas visual koridor secara bersama-sama maupun secara parsial. Besar pengaruh activity support terhadap variabel kualitas visual koridor menurut penghuni sebesar $37,1 \%$, menurut pengunjung sebesar $29,6 \%$, sedangkan secara keseluruhan responden sebesar 35,2\%. Perbedaan hasil ini dipengaruhi oleh perbedaan pengalaman masing-masing responden terhadap koridor jalan K.H. Agus Salim Semarang.

Berdasarkan hasil perhitungan data statistik tersebut, ditemukan bahwa activity support tidak mempunyai hubungan kuat terhadap kualitas visual koridor, dengan faktor bentuk dan optic yang paling dominan. Activity support merupakan elemen perancangan kota yang harus diperhatikan keberadaannya khususnya tampilan visualnya karena akan berpengaruh terhadap keseluruhan kualitas visual sebuah kota. Faktor warna merupakan elemen yang paling mencolok dari visual sebuah bentuk, karena faktor warna akan dapat membedakan sebuah bentuk dari lingkungannya. Akan tetapi dalam menilai activity support faktor bentuklah yang merupakan faktor dominan dalam mempengaruhi nilai visual sebuah activity support. Fakta di lapangan menyatakan 
bahwa activity support yang kurang 'berani' dalam memainkan warna menjadikan faktor warna tidak menjadi paling dominan dalam memberikan pengaruhnya terhadap kualitas visual koridor jalan. Faktor warna kurang mendapatkan tempat sebagai faktor utama pada activity support karena dari waktu ke waktu yang diperhatikan oleh pedagang kaki lima adalah tempatnya untuk bernaung atau dapat dikatakan bentukan dari activity support itu sendiri.

Pemilihan tempat bernaung ini sebagai upaya untuk menjaga barang dagangannya dari sinar matahari dan hujan, karena barang dagangan mereka merupakan hal yang paling utama untuk diperhatikan. Warna dapat membantu penampilan suatu bentuk. Kebanyakan pedagang lebih memilih menggunakan warna asli dari bahan material penyusun kios mereka, seperti warna kayu atau bambu tanpa mengecat ulang bahan tersebut. Warna seadanya itu pun akhirnya kurang membantu penampilan activity support. Adapun pedagang-pedagang yang mengecat kiosnya namun tidak banyak yang menggunakan warna mencolok, padahal warna mencolok mempunyai nilai lebih dalam mempengaruhi kualitas visual koridor dibanding warna senada. Dengan demikian, perbedaan dalam penggunaan warna terkesan tidak mempunyai kesatuan antara satu activity support dengan yang lain. Perhatian terhadap barang dagang pun tidak hanya dilakukan oleh pedagangnya, tidak sedikit pengunjung yang juga lebih memperhatikan barang dagangan yang ditawarkan dibanding perhatiannya terhadap visual activity support yang ditampilkan.

Bentuk dan warna activity support tidak mempunyai keseragaman/keterpaduan sehingga tidak menciptakan kesatuan secara visual yang dapat mempengaruhi faktor place dan optic. Kualitas visual koridor akan berhasil diciptakan dengan baik jika suatu sumber visual memiliki kelengkapan dan saling terpadu. Dengan demikian, bentuk-bentuk activity support yang seragam dan memiliki keterpaduan serta didukung dengan penggunaan warna-warna yang menarik akan menciptakan suatu kesatuan secara visual dan berpengaruh juga pada visual koridor jalan yang akan dirasakan masyarakat. Selain itu, konsistensi antara pemerintah dan masyarakat sebagai aktor utama dalam menentukan kualitasnya juga akan diperhitungkan pengaruhnya.

\section{Kesimpulan}

Berdasarkan hasil analisis data statistik yang telah dilakukan, maka peneliti dapat menjawab pertanyaan penelitian yang pertama, yaitu activity support berpengaruh terhadap kualitas visual koridor Jalan K.H. Agus Salim Semarang. Analisis regresi yang dilakukan menyatakan bahwa variabel activity support memiliki pengaruh secara bersamaan maupun secara parsial terhadap kualitas visual koridor, akan tetapi pengaruh tersebut tidak mempunyai hubungan yang kuat jika dilihat berdasarkan nilai koefisien determinasi. Hipotesis yang dikemukakan peneliti pun terbukti dan sesuai oleh hasil analisis data statistik tersebut.

Pertanyaan kedua mengenai bagaimana pengaruh activity support terhadap kualitas visual koridor dapat dijawab yaitu sebesar $35,2 \%$ activity support berpengaruh pada kualitas visual koridor Jalan K.H. Agus Salim Semarang, sedangkan sebesar 64,8\% dipengaruhi oleh faktor lain di luar model penelitian. Activity support yang didominasi oleh faktor bentuk merupakan faktor yang dapat diamati dan dirasakan langsung visualnya oleh masyarakat. Optic atau urutan pandangan yang disajikan oleh bentuk-bentuk activity support yang ada seperti kios, tendaan dan gerobak yang bercampur di sepanjang koridor jalan memberikan kesan tidak teratur. Kesan tidak teratur ini dibentuk oleh faktor place yang dirasakan oleh masyarakat. Berdasarkan fakta tersebut, dapat disimpulkan bahwa bentuk activity support yang tidak seragam dan tidak membentuk suatu kesatuan di Jalan K.H. Agus Salim telah memberikan visual yang negatif untuk koridor jalan.

\section{Daftar Pustaka}

Ching, Francis, DK. (2000). Arsitektur, Bentuk, Ruang, dan Tatanan, edisi kedua. Ed. Hilarius W. Hardani. Jakarta : Erlangga.

Cullen, Gordon. (1996). The Concise Townscape. Oxford : Butterworth-Heinemann.

Kivanc, Mehmet. (2013). Visual Quality Assessment Methods in Landscape Architecture Studies. Advances in Landscape Architecture, Murat Özyavuz, ed., InTech Chapters, Chapter 11, 279-290.

Krier, Rob. (1979). Urban Space. New York : Rizzoli International Piblication inc.

Mazumdar, S. (2010). Introduction to the special issue: Place, identity and environmental behaviour. Jurnal of Environmental Psycology, Elsevier, 30, 267-270.

Moughtin, Cliff. (2003). Urban Design - Street and Square, Third Edition. Oxford. Architectural Press.

Moughtin, Cliff. (1999). Urban Design : Ornament and Decoration, Second Edition. Oxford. Architectural Press.

Shirvani, Hamid. (1985). The Urban Design Process. New York : Van Nostrand Reinhold Company.

Smardon, et al. (1986). Foundations for Visual Project Analysis. Canada : John Willey and Sons, Inc.

Sugiyono. (2009). Metode Penelitian Kuantitatif, Kualitatif dan R\&D. Bandung: Alfabeta.

Wang, Thomas C. (2006). Sketsa Pensil. Terjemahan Ir. Zulfikri Harahap. Jakarta : Erlangga. 